\title{
CORRELATION BETWEEN MEDICAL STUDENTS' PERCEPTION ON LEARNING ENVIRONMENT AND STRESS LEVEL
}

\author{
Resti Rahmadika Akbar*, Mardiastuti Wahid**, Retno Asti Werdhani*** \\ * Medical Education Unit, Faculty of Medicine Universitas Baiturrahmah, Padang - INDONESIA \\ ** Department of Microbiology Faculty of Medicine Universitas Indonesia, Jakarta - INDONESIA \\ *** Department of Community Medicine, Faculty of Medicine Universitas Indonesia, Jakarta - INDONESIA
}

\begin{abstract}
Background: Learning environment in medical education is one of several aspect determine students' academic success. The medical education itself has been the biggest source of depression or stress for students, beside personal, financial, or family problems. The purpose of this study is to assess the correlation between students' perception on learning environment and stress levels.
\end{abstract}

Methods: This study was a cross sectional study, conducted from December 2016 to April 2017, involving the $1^{\text {st }}, 2^{\text {nd }}, 3^{\text {rd }}, 4^{\text {th }}$ year students of the Faculty of Medicine, Baiturrahmah University (FK UNBRAH), Padang, with a total of 595 students. Students' perceptions on learning environment were assessed using the Dundee Ready Educational Environment Measure (DREEM) questionnaire and the student stress level was assessed by the questionnaire of Depression Anxiety Stress Scale 42 (DASS 42). Both questionnaires have been validated and available in Bahasa.

Results: Respondents involved in this study were 477 (80.1\%). The median of the students's perceptions on their learning environment was 132 (92-200), which means "more positive than negative". Students' perceptions on learning environment between $1^{\text {st }}$ year students with other academic years differed significantly. There was no significant difference between female and male students' perceptions on the learning environment. The median value of student stress level of FK UNBRAH was categorized as normal. There was no statistically significant difference in stress level based on academic level and gender. The correlation between students' perception toward learning environment and academic level was found to be significant with very weak negative correlation $(p<0,05)$

Conclusion: The better students' perception on the learning environment, the lower the stress level.

Keywords: Educational environment, stress level, medical student in academic process, DASS questionnaire, DREEM questionnaire

\begin{abstract}
ABSTRAK
Latar belakang: Lingkungan pembelajaran pada pendidikan kedokteran menentukan kesuksesan akademik mahasiswa. Akan tetapi, pendidikan kedokteran merupakan sumber terbesar yang menyebabkan mahasiswa stres, selain masalah pribadi, finansial ataupun masalah keluarga. Tujuan dari penelitian ini untuk menilai hubungan antara persepsi mahasiswa terhadap lingkungan pembelajaran dengan tingkat stres mahasiswa.

Metode: Penelitian ini merupakan studi dengan desain potong lintang, dilaksanakan mulai dari Desember 2016 sampai Juni 2017, melibatkan mahasiswa tingkat I, II, III dan IV Fakultas Kedokteran Universitas Baiturrahmah (FK UNBRAH), Padang, dengan total jumlah mahasiswa 595 orang. Persepsi mahasiswa terhadap lingkungan pembelajaran dinilai menggunakan kuesioner Dundee Ready Educational Environment Measure (DREEM) dan tingkat stres mahasiswa dinilai dengan kuesioner Depresion Anxiety Stress Scale (DASS) 42. Kedua kuesioner telah tervalidasi dan tersedia dalam Bahasa Indonesia.
\end{abstract}

contact: restirahmadikaakbar@gmail.com 
Hasil: Responden yang terlibat dalam penelitian ini sejumlah 477 (80,1\%). Persepsi seluruh mahasiswa terhadap lingkungan pembelajaran didapatkan nilai median 132(92-200), yang bermakna "lebih banyak positif dibandingkan negatif". Terdapat perbedaan bermakna persepsi mahasiswa tingkat I terhadap lingkungan pembelajaran dengan tingkat lainnya. Tingkat stres mahasiswa FK UNBRAH termasuk kategori normal. Hubungan persepsi mahasiswa terhadap lingkungan pembelajaran dan tingkat akademik bermakna dengan korelasi negatif sangat lemah $(p<0,05)$.

Kesimpulan: Semakin baik persepsi mahasiswa terhadap lingkungan pembelajaran, semakin rendah tingkat stres mahasiswa.

Kata kunci: Lingkungan pembelajaran, tingkat stress, mahasiswa tahap akademik, kuesioner DASS, kuesioner DREEM

\section{INTRODUCTION}

Learning environment is all elements which interacts with students, whether it is in the learning process, teacher, academic achievement, learning condition and social environment. A good learning environment is the one that can provide the students to reach their expected competency. A lot of research had been done to prove that a good learning environment will have an impact to the learning success rate of the students. ${ }^{1}$

World Federation Medical Education (WFME) recommends to perform evaluation of learning environment. Learning environments helps to identify strength and area of improvement which has an effect to the students' performance and decides the success of an institution. ${ }^{2}$

During learning process, medical student may be exposed to various demands which may results in stress. Stress is caused by the mismatch between expectation with reality and self worth with challenges. One of the factors that may cause stress is academic burden. ${ }^{3-7}$

There are positive and negative impacts of stress. The postitive effects, if the individual can handle the stress and turns the stress as a stimulus to perform better. The negative effects may affect academic performance, may causes anxiety, depression, mental problem, boredom, burnout, alcohol consumption and drugs abuse, and worse of all, suicide. ${ }^{8-11}$

The possibility of learning environment as a potential stress factor for medical students is yet to be discovered. In Indonesia, researches regarding learning environment had been carried out, along with stress level of medical students. However, no research has been done to find a correlation between these two aspects.

\section{METHODS}

The type of research used is correlational research with a cross-sectional study design. Sampling technique used was total sampling involving medical students from $1^{\text {st }}, 2^{\text {nd }}, 3^{\text {rd }}, 4^{\text {th }}$ year. The number of respondents involved was students. This research was done at Faculty of Medicine, Baiturrahmah University (FK UNBRAH). Sampling was done using online questionnaires. Students were divided into small groups according to academic level. Before filling in the informed consent and proceeds to fill in the questionnaires, we explained the research background and objectives.

\section{DREEM questionnaire}

DREEM questionnaire on assess student's perception on learning environment which consists of 50 questions, scoring is done using Likert score. For each response, the grading is as follows; $4=$ strongly agree, $3=$ agree, $2=$ not sure $1=$ disagree, $0=$ strongly disagree. DREEM questionnaire is split into five subscales which are students' perception on learning (SPL-12 questions), teacher (SPT-11 questions), academic self perception (SASP-8 questions), learning atmosphere (SPA-12 questions) and social self perception (SSSP-7 questions). There are 9 questions that have negative scores which 
are number $4,8,9,17,25,35,39,48$ and 50 , and should be filled oppositely. ${ }^{9,12,13}$ The guideline for all scoring is as follows:

- $0-50$ : poor perception of learning environment

- 51-100 : a lot of problem

- 101-150: more positives than negatives

-151-200: good

\section{DASS 42 questionnaire}

Stress level was assessed using DASS 42 questionnaire, which was developed by Lovibond and Lovibond, and been validated and translated to Indonesian language. This questionnaire was designed to assess negative emotional condition of depression, anxiety and stress. In accordance to the aim of this research, which is to evaluate stress aspects of the students, only scores regarding stress was marked and evaluated. Stress score was calculated by adding up the scores which were relevant to stress domain. Scoring was also done using Likert score, $3=$ very often, $2=$ quite often, $1=$ occassionaly, $0=$ never. Stress level was categorized into several stress scores level, 0-14: normal, 15-18 mild, 19-25 moderate, 26-33 severe, $>34$ very severe..$^{5,14}$

\section{Data analysis}

Data obtained was analysed using SPSS 20.0. The data was not normally distributed. The total scores and subscale scores of DREEM questionnaire according to the academic year with academic grade was assessed using Kruskal Wallis, while gender was assessed using Mann-Whitney. Stress level in academic year and gender were analyzed using Chi Square. To evaluate student's perception on learning environment and stress level, we applied the Spearman test.

\section{RESULTS AND DISCUSSION}

Table 1 below describe the characteristics of respondents, more respondents are $<20$ years old, female respondents 3 times more than men. The first year medical students is the one with the higest percentage as a respondent followed by the $2 \mathrm{nd}, 3 \mathrm{rd}$ and 4 th year students.

Table 1. Respondents' Characteristics $(n=477)$

\begin{tabular}{|c|c|c|c|c|c|}
\hline Variable & & & & $\mathrm{n}$ & $\%$ \\
\hline \multicolumn{6}{|l|}{ Age } \\
\hline$<20$ years old & & & & 283 & 59,33 \\
\hline$>20$ years old & & & & 194 & 40,67 \\
\hline \multicolumn{6}{|l|}{ Gender } \\
\hline Male & & & & 102 & 21,38 \\
\hline Female & & & & 375 & 78,62 \\
\hline Academic year & Total students & Total respondents & $\%$ & & \\
\hline $1^{\text {st }}$ year & 149 & 126 & 84,6 & 126 & 26,42 \\
\hline $2^{\text {nd }}$ year & 80 & 65 & 81,3 & 65 & 13,63 \\
\hline $3^{\text {rd }}$ year & 168 & 134 & 79,8 & 134 & 28,09 \\
\hline $4^{\text {th }}$ year & 198 & 152 & 76,8 & 152 & 31,87 \\
\hline
\end{tabular}

\section{Student's perception on learning environment of the Faculty of Medicine Baiturrahmah University}

Median total DREEM score was 132(92-200).

Post hoc Mann Whitney test of $1^{\text {st }}$ year student's perception regarding the learning environment was statistically significant for all academic year. The results of DREEM are described in Table 2. 
Table 2. Student's perception on learning environment

\begin{tabular}{|c|c|c|c|c|c|c|c|c|c|}
\hline \multirow{2}{*}{$\begin{array}{l}\text { Sub- } \\
\text { scale }\end{array}$} & \multirow{2}{*}{$\begin{array}{c}\text { Median } \\
(\min - \\
\max )\end{array}$} & \multicolumn{4}{|c|}{ Academic year } & \multirow{2}{*}{$\begin{array}{l}\text { p Kruskal } \\
\text { Wallis }\end{array}$} & \multicolumn{2}{|c|}{ Gender } & \multirow{2}{*}{$\begin{array}{l}\text { p Mann } \\
\text { Whitney }\end{array}$} \\
\hline & & $1^{\text {st }}$ year & $2^{\text {nd }}$ year & $3^{\text {rd }}$ year & $4^{\text {th }}$ year & & Male & Female & \\
\hline Total & $\begin{array}{c}132 \\
(92-200)\end{array}$ & $\begin{array}{c}135 \\
(92-200)\end{array}$ & $\begin{array}{c}129 \\
(92-158)\end{array}$ & $\begin{array}{c}131,5 \\
(107-176)\end{array}$ & $\begin{array}{c}132 \\
(103-161)\end{array}$ & $<0,001$ & $\begin{array}{c}134 \\
(94-176)\end{array}$ & $\begin{array}{c}132 \\
(92-200)\end{array}$ & 0,282 \\
\hline SPL & $\begin{array}{c}33 \\
(18-48)\end{array}$ & $\begin{array}{c}34 \\
(22-48)\end{array}$ & $\begin{array}{c}32 \\
(18-42)\end{array}$ & $\begin{array}{c}33 \\
(25-45)\end{array}$ & $\begin{array}{c}33 \\
(22-41)\end{array}$ & 0,001 & $\begin{array}{c}33,5 \\
(22-45)\end{array}$ & $\begin{array}{c}33 \\
(18-48)\end{array}$ & 0,445 \\
\hline SPT & $\begin{array}{c}26 \\
(16-44)\end{array}$ & $\begin{array}{c}26,5 \\
(18-44)\end{array}$ & $\begin{array}{c}26 \\
(20-34)\end{array}$ & $\begin{array}{c}26 \\
(16-33)\end{array}$ & $\begin{array}{c}26 \\
(20-35)\end{array}$ & 0,227 & $\begin{array}{c}27 \\
(19-33)\end{array}$ & $\begin{array}{c}26 \\
(16-44)\end{array}$ & 0,200 \\
\hline SASP & $\begin{array}{c}24 \\
(16-48)\end{array}$ & $\begin{array}{c}24 \\
(18-32)\end{array}$ & $\begin{array}{c}23 \\
(14-29)\end{array}$ & $\begin{array}{c}23 \\
(17-31)\end{array}$ & $\begin{array}{c}24 \\
(15-31)\end{array}$ & $<0,001$ & $\begin{array}{c}24 \\
(15-32)\end{array}$ & $\begin{array}{c}24 \\
(14-32)\end{array}$ & 0,566 \\
\hline SPA & $\begin{array}{c}32 \\
(16-48\end{array}$ & $\begin{array}{c}33 \\
(17-48)\end{array}$ & $\begin{array}{c}30 \\
(22-40)\end{array}$ & $\begin{array}{c}31 \\
(20-43)\end{array}$ & $\begin{array}{c}31 \\
(16-42)\end{array}$ & $<0,001$ & $\begin{array}{c}32 \\
(16-44)\end{array}$ & $\begin{array}{c}31 \\
(17-48)\end{array}$ & 0,361 \\
\hline SSSP & $\begin{array}{c}18 \\
(10-28)\end{array}$ & $\begin{array}{c}18 \\
(11-28)\end{array}$ & $\begin{array}{c}17 \\
(13-22)\end{array}$ & $\begin{array}{c}18 \\
(12-25)\end{array}$ & $\begin{array}{c}18 \\
(10-24)\end{array}$ & 0,006 & $\begin{array}{c}19 \\
(12-25)\end{array}$ & $\begin{array}{c}18 \\
(10-28)\end{array}$ & 0,154 \\
\hline
\end{tabular}

SPL : Students' perception on learning

SPT : Students' perception on teacher

SASP: Students' academic self perception

Statistic analysis for subscale SPL and SPA showed significant difference. Post hoc Mann Whitney test for $1^{\text {st }}$ year student showed significant difference when compared with students from other academic years $(p<0,05)$. Statistic analysis for subscale SASP showed significant difference. Post hoc Mann Whitney analysis of subscale SASP among academic years showed significant difference $\mathrm{p}<0,05$, except between $2^{\text {nd }}$ and $3^{\text {rd }}$ year students. Post hoc Mann Whitney analysis of subscale SSSP showed significant difference between $2^{\text {nd }}$ and $3^{\text {rd }}$ year students $(p=0,002)$ and between $1^{\text {st }}$ and $2^{\text {nd }}$ students $(\mathrm{p}=0,003)$.

Student's perception between learning environment and its subscale based on gender, indicated a similar result which was "more postives than negatives". Mann Whitney test showed that there was no significant difference between perception of male and female students regarding the learning environment and its subscale $(\mathrm{p}>0.05)$.

DREEM questionnaire gives a general idea about student's perception towards learning environment and 5 subscales. Median score of student's perception towards learning environment was 132(92-200). This score was a little bit higher than
SPA : Students' perception on atmosphere SSSP: Students' social self perception

DREEM scores from Aga Khan Faculty of Medicine in Pakistan which was $126 .{ }^{15}$ High DREEM results score was obtained by Faculty of Medicine Tanjung Pura University in $2015(142,55) .{ }^{16}$

There are 3 statements of SPL subscale with median score of 2; "time for learning activities was spent appropriately", learning activities puts too much emphasis on factual learning " and "learning activities is too teacher-centered. From, those 3 statements, we can conclude that the learning process is dominated by (teacher-centered) rather than student-centered ${ }^{17}$. Learning is made up of lectures, hence students felt that they do not take enough part during learning process. Students felt they were still unable to manage their time efficiently. ${ }^{18}$

For SPT subscale, there were 4 statements with median score of 2 and 1 . Those statements were teaching staffs insult students; teaching staffs acts authoritatively; teaching staffs show anger in front of the class; students annoy the teaching staffs. The statement "teaching staffs acts authoritatively" is related to learning process subscale which indicates that learning process is still centered towards teacher/lecturer, hence students still think that 
all decision came from teacher. The statement "teaching staffs show anger in front of the class" and "teaching staffs insult students" shows that teaching staffs should be refreshed by attending role model training. Teaching staffs should be responsible for learning environment, therefore teaching staffs in medical school should be provided with not only knowledge and skills, but also moral values. ${ }^{18}$

Some statements of SASP subscale has a median score of 3 nd 4 . This indicates that students has motivation and optimism in doing learning process. Based on previous research, it is known that perception regarding academic achievement and motivation level can predicts actual academic achievement. ${ }^{17,19}$

Statements regarding SPA subscale which has a median score of 2 is "I had an unpleasant experiences". This should be explored further to find out the cause of disappointment. There is a need for a facilities or a support system that handle students problems. Other support system, such as academic coordinator can be utilized to solve these problems, so that the quality of student's performance can be improved. ${ }^{17}$

Statements on SSSP subscale in which median scores $\leq 2$, are as follows: "there is a good support system for students who experience stress", "I am too tired to be able to enjoy this education process", and "I rarely feel bored during this education process". Again, this indicates the urgency in the development of student support system to facilitate learning and provides students' comfortness. The same results was also observed in Dasputra A et al ${ }^{18}$ research, in private medical faculty in India, which showed lower score on the statement "there is a good support system for students who experience stress". In this research, students were given open ended questions regarding their expectation for support system during medical education process. Students suggested the need of recreation center, cafeteria, stress management program, and less teacher-centered learning. ${ }^{18,19}$

Student's perception towards learning environment according to academic year is more positive than negative perception. First year students has a median score which is higher than other academic year Research conducted at Faculty of Medicine Sharjah and Sultan Zainal Abidin University in Malaysia showed students from year I had better perception compared to their seniors. ${ }^{20,21}$

There is a significant difference between student's perception towards learning environment for subscale SPL and SPA for all year and $1^{\text {st }}$ year. Subscale SPT does not show significant difference in all academic year. Student's perception subscale towards academic achievement significant difference is only observed in $2^{\text {nd }}$ year and $3^{\text {rd }}$ year students. On the other hand, subscale SSSP of $2^{\text {nd }}$ and $3^{\text {rd }}$ year, $1^{\text {st }}$ and $2^{\text {nd }}$ year shows significant difference.

Median score of student's perception towards learning environment shows higher score for male compared to female students, but it does not significant difference statistically. Similar were observed in India that also showed lower perception of female students compared to male students regarding their learning environment. ${ }^{22}$ Different results were reported by Altemani, Rehman and Al-Naggar, student's perception towards learning environment in medical students in Saudi Arabia showed that women fares better compared to male students. ${ }^{23-25}$ In this regards, we conclude that learning environmemnt does not depend on gender.

\section{Stress level of students of Faculty of Medicine Baiturrahmmah University}

Students' stress level is described in Table 3. Stress level evaluation using DASS questionnaire showed median score of 12(0-41). Stress level of medical students of Faculty of Medicine Baiturrahmah University was categorized as normal. According to the percentage trend, $1^{\text {st }}$ year students wasmore stressful than the other academic year. Chi Square test did not show significant difference between stress level and academic year $(p=0.053)$. Based on stress level, female students compared male students did not show significant difference (Chi Square test). 
Table 3. Student's stress level $(n=477)$

\begin{tabular}{|c|c|c|c|c|c|c|c|}
\hline \multirow[b]{2}{*}{ Stress Level } & \multirow[b]{2}{*}{$\begin{array}{c}\mathrm{N} \\
(\%)\end{array}$} & \multicolumn{4}{|c|}{ Academic Grade } & \multicolumn{2}{|c|}{ Gender } \\
\hline & & $1^{\text {st }}$ year & $2^{\text {nd }}$ year & $3^{\text {rd }}$ year & $4^{\text {th }}$ year & $\begin{array}{c}\text { Male } \\
(\mathrm{n}=102)\end{array}$ & $\begin{array}{c}\text { Female } \\
(\mathrm{n}=375)\end{array}$ \\
\hline Normal & $\begin{array}{c}338 \\
(70,9 \%)\end{array}$ & $\begin{array}{c}82 \\
(24,3 \%)\end{array}$ & $\begin{array}{c}44 \\
(13,0 \%)\end{array}$ & $\begin{array}{c}101 \\
(29,9 \%)\end{array}$ & $\begin{array}{c}111 \\
(32,8 \%)\end{array}$ & $\begin{array}{c}81 \\
(79,4 \%)\end{array}$ & $\begin{array}{c}257 \\
(68,5 \%)\end{array}$ \\
\hline Mild & $\begin{array}{c}79 \\
(16,6 \%)\end{array}$ & $\begin{array}{c}20 \\
(25,3 \%)\end{array}$ & $\begin{array}{c}12 \\
(15,2 \%)\end{array}$ & $\begin{array}{c}19 \\
(24,1 \%)\end{array}$ & $\begin{array}{c}28 \\
(35,4 \%)\end{array}$ & $\begin{array}{c}13 \\
(12,7 \%)\end{array}$ & $\begin{array}{c}66 \\
(17,6 \%)\end{array}$ \\
\hline Moderate & $\begin{array}{c}45 \\
(9,4 \%)\end{array}$ & $\begin{array}{c}14 \\
(31,1 \%)\end{array}$ & $\begin{array}{c}8 \\
(17,8 \%)\end{array}$ & $\begin{array}{c}12 \\
(26,7 \%)\end{array}$ & $\begin{array}{c}11 \\
(24,4 \%)\end{array}$ & $\begin{array}{c}7 \\
(6,9 \%)\end{array}$ & $\begin{array}{c}38 \\
(10,1 \%)\end{array}$ \\
\hline Severe & $\begin{array}{c}12 \\
(2,5 \%)\end{array}$ & $\begin{array}{c}8 \\
(66,7 \%)\end{array}$ & $\begin{array}{c}1 \\
(8,3 \%)\end{array}$ & $\begin{array}{c}2 \\
(12,7 \%)\end{array}$ & $\begin{array}{c}1 \\
(8,3 \%)\end{array}$ & $\begin{array}{c}1 \\
(1,0 \%)\end{array}$ & $\begin{array}{c}11 \\
(2,9 \%)\end{array}$ \\
\hline Very Severe & $\begin{array}{c}3 \\
(0,6 \%)\end{array}$ & $\begin{array}{c}2 \\
(66,7 \%)\end{array}$ & $\begin{array}{c}0 \\
(0,0 \%)\end{array}$ & $\begin{array}{c}0 \\
(0,0 \%)\end{array}$ & $\begin{array}{c}1 \\
(33,3 \%)\end{array}$ & $\begin{array}{c}0 \\
(0,0 \%)\end{array}$ & $\begin{array}{c}3 \\
(0,8 \%)\end{array}$ \\
\hline
\end{tabular}

In general, the stress level of students from Faculty of Medicine Baiturrahmah University is dominated with normal stress level, which means that students can adapt towards all the learning environment, without showing signs of emotional distress. Some researches showed that $1^{\text {st }}$ year student was more stressful due to adaptation to new environments, learning process and other factors. Stress level will decrease as the students ascends to higher academic year and raise again during the transition from pre-clinical rotation to clinical rotation when students experience another new experiences or situations. ${ }^{25,26}$ In this study, this situation also observed in the $1^{\text {st }}$ and $4^{\text {th }}$ year students (the final year of pre-clinical rotation). Stress level experienced by the $1^{\text {st }}$ and $4^{\text {th }}$ year students is higher than the $2^{\text {nd }}$ and $3^{\text {rd }}$ year students.

Students in the first year are the group who is more prone to stress, as mentioned before, they need to adapt from life as senior high school students to become medical students. First year students face orientation program and learning process that differs from senior high school. They also face with tight lecture schedule. ${ }^{25}$ So that, it may cause emotional disturbances.

Female students are more stressful than their male counterparts since they express their feelings more than male. ${ }^{27}$ This is in accordance with research of Agolla \& Ongori ${ }^{26}$ which showed higher stress level in female than male. Stres level are related to caping mechanisms, defined as any effort used to manage stress. Coping mechanisms are influenced by physiological, psychological, social and cultural factors. Differences in coping mechanisms used by male with female are caused by physiological factors, female tend to use a coping mechanism that focuses on emotions while male focus on problem solving, hence male is seen more relaxed when faced with stress originated from academic life. ${ }^{26,27}$

\section{Correlation between student's perception between learning environment and student's stress level}

Student's perception on learning environment and stress level indicated significant correlation with very weak negative correlation. There are three subscales: SASP, SPA and SSSP which showed significant difference with stress level although it has weak negative correlation or very weak negative correlation. Evaluation of correlation between student's perception on learning environment and stress level according to academic year, showed significant correlation in $2^{\text {nd }}$ year students with quite strong negative correlation, for total DREEM scores $(\mathrm{p}=0,012, \mathrm{r}=-0,310)$, SASP $(\mathrm{p}=0,004, \mathrm{r}=-0,352)$, SPA $(p=0,004, r=-0,357)$ and SSSP $(p=0,007, r=$ $0,332)$. For the $4^{\text {th }}$ year students, significance was observed only in SSSP $(p=<0,001, r=-0,335)$. The results can be seen in Table 4 . 
Table 4. Correlation between student's perception on earning environment and student's stress level Faculty of Medicine Baiturrahmah University $(n=477)$

\begin{tabular}{lcc} 
& \multicolumn{2}{c}{ Stress Level } \\
\cline { 2 - 3 } & $\mathbf{P}$ & \multicolumn{1}{c}{$\mathbf{R}$} \\
Total DREEM & 0,035 & $-0,096$ \\
SPL & 0,577 & $-0,26$ \\
SPT & 0,266 & $+0,051$ \\
SASP & 0,010 & $-0,118$ \\
SPA & 0,024 & $-0,104$ \\
SSSP & 0,000 & $-0,212$ \\
\hline
\end{tabular}

Student's perceptions on learning environment correlated significantly with stress level, eventhough the correlation is very weak and towards negative. Students with positive perspective towards their learning environment has a normal or mild stress level. Research done by Faculty of Dentistry Malaya University regarding perception of students towards learning environment and its correlation with stress level between $1^{\text {st }}$ year students, using DREEM questionnaire and DASS 21, showed no significant correlation with negative trends. Students faced difficulties in answering specific questions listed on the questionnaire regarding the learning environment. DASS questionnaire does not assess financial problem, which is also a source of stress. Therefore resulted in insignificant difference. ${ }^{28}$

Based on the academic year, the $2^{\text {nd }}$ year students have a higher significant relationship of students' perceptions on their learning environment and stress level. This can prove the existence of the process of adaptation of students to the environment so as to reduce stress levels. ${ }^{11}$

\section{Limitation}

This research does not explore the source of students' stress. The instruments used to assess stress can only be used to assess the stress level in general, not specifically applied for medical students. Another limitation is that DREEM questionnaire assess learning environment from the begining of the leraning process until this moment, while DASS 42 questionnaire expect the students to assess themselves up until one week before sampling. This difference may causes bias. Another thing, the sampling period which coincided with examination period may cause more stress to the students compared when it is taken early in the module.

\section{CONCLUSION}

There is a significant correlation between perception of students to learning environment and stress level with correlation power being very weak. A stronger correlation between certain subscales of learning environment.and stress level was found in the $2^{\text {nd }}$ year and $4^{\text {th }}$ year students. In conclusion, the better the perception of students on learning environment, the lower the students' stress level.

\section{REFERENCES}

1. McAleer S, Roff S. Educational environment. Dalam: Dent JA, Harden RM, eds. A practical guide for medical teachers. $4^{\text {th }}$ edition. London: Churchill Livingstone: Elsevier; 2013;392-399.

2. The Executive Council WMFE. International standarts in medical education: assessment and accreditation of medical school's educational programmes: A WFME position paper. Med Educ. 1998;32:549-558.

3. Albulghani H. Stress and depression among medical students: a cross sectional study at medical college in Saudi Arabia. Pak J Med Sci. 2008;24(1):12-17.

4. Salam A, Yousuf R, Muhammad S, Bakar A, Haque M. Stress among medical students in Malaysia: A systematic review of literatures. Int Med J.2013;20(6):649-655.

5. Dahlin M, Joneborg N, Runeson B. Stress and depression among medical students: a crosssectional study. Med Edu 2005;39:594-604.

6. Rahman NIA, Aziz AA, Zulkifli Z, Haj MA, Mohd Nasir FHB, Pergalathan S, dkk. Perceptions of students in different phases of medical education of the educational environment: Universiti Sultan Zainal Abidin. Adv Med Educ Pract [Internet]. 2015;6:211-222. Available at: http:// www.pubmedcentral.nih.gov/articlerender. fcgi $?$ artid $=4378299 \&$ tool=pmcentre $\&$ rendertype. Downloaded April $7^{\text {th }} 2017$

7. Rasmun. Pengertian stres, sumber stres, dan sifat stresor. dalam: stres, koping, dan adaptasi. Jakarta: Sagung Seto; 2004. 9-26

8. Soemantri D, Roff S, Mcaleer S. Student perceptions' of the educational environment in 
the midst of curriculum change. Med J Indones 2008;17(1):57-63.

9. Abraham R, Ramnarayan K, Vinod P, Torke S. Students' perceptions of learning environment in an Indian Medical school. BMC Med Edu. 2008;5:1-5. Available at: http:// www.biomedcentral.com/1472-6920/8/20. Downloaded September 30 2016

10. Shapiro SL, Shapiro DE, Schwartz GER. Stress management in medical education : a review of the literature. Acad Med J 2000; 75:748-759

11. Alfaris EA, Naeem N, Irfan F, Qureshi R, Vleuten C Van Der. Student centered curricular elements are associated with a healthier educational environment and lower depressive symptoms in medical students. BMC Med Edu 2014; 14:192-198. Available at: http:// www.biomedcentral.com/1472-6920/14/192. Downloaded November $23^{\text {rd }} 2016$

12. Vaughan B, Carter A, Macfarlane C, Morrison T. The DREEM, part 1 : measurement of the educational environment in an osteopathy teaching program. BMC Med Edu 2014;111. Available at: http://www.biomedcentral. com/1472-6920/14/99. Downloaded June $15^{\text {th }}$ 2016

13. Colbert-Getz JM, Kim S, Goode VH, Shochet RB, Wright SM. Assessing medical students' and residents' perceptions of the learning environment : interpretation of scores from existing tools. Acad med J 2014;XXX(Xxx):1-7

14. Lovibond PF, Lovibond SH. The structure of negative emotional states: Comparison of the Depression Anxiety Stress Scales (DASS) with the Beck Depression and Anxiety Inventories. Behav Res Ther. 1995;33(3):335-43.

15. Rehman R, Ghias K, Fatima SS, Hussain M, Alam F. Students' perception of educational environment at Aga Khan University Medical College, Karachi, Pakistan. Pak J Med Sci 2016;32(3):7-11.

16. Malik R. Hubungan persepsi mahasiswa tentang lingkungan pembelajaran terhadap pendekatan belajar pada mahasiswa semester enam Fakultas Kedokteran Universitas Tarumanegara. Universitas Indonesia; Tesis. 2014.
17. Palés J, Gual A, Escanero J, Tomás I, Rodríguezde Castro F, Elorduy M, dkk. Educational climate perception by preclinical and clinical medical students in five Spanish medical schools. Int J Med Educ. 2015;6:65-75.

18. Dashputra A, Chari S, Gade S. Perception of educational environment in a private medical college in Central India. Int J Edu Sci 2014;6(3):489-496.

19. Miles S, Swift L, Leinster SJ, et al. The Dundee Ready Education Environment Measure (DREEM): A review of its adoption and use The Dundee Ready Education Environment Measure (DREEM): A review of its adoption and use. Epub ahead of print 2016. DOI: $10.3109 / 0142159 X .2012 .668625$.

20. Sarwar S, Tarique S. Perception of educational environment: Does it impact academic performance of medical students? J Pak Med Assoc. 2016;66(10):1210-1214.

21. Nosair E, Mirghani Z, Mostafa RM. Measuring students ' perceptions of educational environment in the PBL program of Sharjah Medical College. JMECD 2015;71-79.

22. Al-Naggar RA, Abdulghani M, Osman MT, AlKubaisy W, Daher AM, Nor Aripin KN, dkk. The Malaysia DREEM : perceptions of medical students about the learning environment in a medical school in Malaysia. JAMEP 2014;177-184.

23. Abraham RR, Ramnarayan K, Pallath V, Torke S, Madhavan M, RoffS. Perceptions of academic achievers and under-achievers regarding learning environment of Melaka Manipal Medical College (Manipal campus), Manipal, India, using the DREEM Inventory. South East Asian J Med Educ. 2007;1:18-24.

24. Altemani AH, Merghani TH. The quality of the educational environment in a medical college in Saudi Arabia. Int J Med Educ [Internet]. 2017;8:128-1. Available at: https://www.ijme. net/archive/8/educational-environment-in-saudiarabia.pdf. Downloaded in April 5 ${ }^{\text {th }} 2017$

25. Rehman R, Ghias K, Fatima SS, Hussain M, Alam F. Dream of a conducive learning environment: One DREEM for all medical students! J Pak Med Assoc. 2017;67(1):7-11

26. Navas SP. Stress among medical students. Kerala Med J [Internet]. 2012;5(2):34-7. Available at: http://journals.publishmed.com/index.php/KMJ/ article/view/303. Downloaded in April $7^{\text {th }} 2017$

27. Babar MG, Hasan SS, Ooi YJ, et al. Perceived sources of stress among Malaysian dental students. 2015; 56-61. 
28. Talwar P, Rahman MF. Factor structure of general health questionnaire and assessment: A crosssectionalstudyamonguniversitystudentsin Malaysia. ASEAN J Psychiatry [Internet]. 2015;16(2):23240. Available at: http://search.ebscohost.com/login. aspx ?direct $=$ true $\& \mathrm{db}=$ psyh $\& A N=2016-00139$. $011 \&$ site $=$ ehost-live $\&$ scope $=$ site $\% 5$. Downloaded in April 6 ${ }^{\text {th }} 2017$

29. Godefrooji MB, Diemers AD. Student's perceptions about transition to the clinical phases of a medical curriculum with patient contacts; a focus group study. BMC Med Edu 2010; 10:28-37. Available at: http://www.biomedcentral.com/1472-6920/10/28. Downloaded in June 192017

30. Kyaimon M, Hoe S, Ruby H, Rosnah I. Dental Students' Educational Environment and Perceived Stress : The University of Malaya Experience. Malay J Med Sci 2016;23(3):49-56. 